\title{
22. A prezidenciális jelleg hangsúlyossága a különleges jogrend romániai szabályozásában
}

\author{
SZENTPÁLI-GAVALLÉR PÁL
}

\section{A különleges jogrend alkotmányos és törvényi szintü szabályozása, esetkörei}

A román jogrendszerben az alkotmány ${ }^{1}$ (elfogadva 1991-ben, módosítva 2003-ban)² nem szentel önálló fejezetet a különleges jogrend kérdésének, hanem a Románia elnökéről szóló fejezet egyes szakaszai rendelkeznek az ilyen helyzetekről. A további különleges jogrendi szabályokat a törvényi és rendeleti szabályozás tartalmazza. Az utóbbi rendeleti szabályozás vonatkozásában a későbbiekben sajátos szabályozási megoldások is bemutatásra kerülnek, az idekapcsolódó alkotmánybírósági gyakorlat vázolásával.

1 Románia alkotmánya (Constituţia României) (a továbbiakban: alkotmány).

2 Ahogy Varga Attila is rámutat, a 2003-as sikeres alkotmánymódosítás, valamint a 2011-es és 2013-as sikertelen alkotmánymódosítási kísérletek során az alkotmány felülvizsgálatának alternatívájaként egyaránt felmerült (igaz, inkább csak elméleti vitaként) egy új alkotmány elfogadásának a lehetôsége, valamint szükségessége (Varga, 2019, 83. o.).

Dr. Szentpáli-Gavallér Pál

pal.szentpali-gavaller@mfi.gov.hu

kutató (Mádl Ferenc Összehasonlító Jogi Intézet)

PhD-hallgató (Miskolci Egyetem, Deák Ferenc Állam- és Jogtudományi Doktori Iskola)

Szentpáli-Gavallér, P. (2021) 'A prezidenciális jelleg hangsúlyossága a különleges jogrend romániai szabályozásában' in Nagy, Z., Horváth, A. (szerk.) A különleges jogrend és nemzeti szabályozási modelljei, 480-503. o. Budapest: Mádl Ferenc Összehasonlító Jogi Intézet.

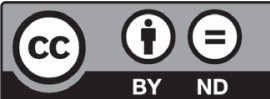


Az alkotmány a köztársasági elnökről szóló fejezetben részletezi az ostromállapotot és a sürgősségi állapotot mint kivételes intézkedéseket, valamint az alkotmány³ organikus törvény szabályozási körébe utalja egyfelől a részleges vagy teljes mozgósítás állapotának és a hadiállapot jogállásának a szabályozását mint az ország elleni fegyveres támadásra adott választ. Az ostromállapotot és a sürgősségi állapotot ugyanaz a sürgősségi kormányrendelet ${ }^{4}$ szabályozza, a mozgósítás és a hadiállapot szabályait pedig törvény ${ }^{5}$ rögzíti.

$\mathrm{Az}$ alkotmány és az annak alapján elfogadott legjelentősebb jogforrások ${ }^{6}$ tehát különbséget tesznek a következők között:

- az ostromállapot és a sürgósségi állapot mint a legmagasabb fokú veszélyhelyzettípusok, amelyek esetében Románia elnöke és a parlament rendelkezik alapvető hatáskörrel;

- a sürgősségi helyzet mint magas fokú veszélyhelyzet, amelynek esetében a kormány rendelkezik alapvető hatáskörrel; és

- a riadóállapot, amely alacsonyabb fokú veszélyhelyzetet feltételez, és amelyet szintén a kormánynak kell kezelnie.

Az ostromállapot (starea de asediu) olyan rendkívüli, politikai, katonai, gazdasági, szociális vagy más jellegú intézkedéseket jelöl, amelyeket egyes területi-közigazgatási egységekben vagy az ország egész területén az állam honvédelmi kapacitásainak súlyos, aktuális vagy elkerülhetetlen, a szuverenitást, a függetlenséget, az egységet és területi épséget fenyegető veszély elhárítása érdekében történő mozgósításra foganatosítanak.

A sürgősségi állapot ${ }^{7}$ (starea de urgență) olyan rendkívüli, politikai, gazdasági és közrendi jellegű intézkedéseket jelöl, amelyeket egyes területi-közigazgatási egységekben vagy az ország egész területén, a következő esetekben foganatosítanak:

- a nemzetbiztonságot vagy az alkotmányos demokráciát fenyegető súlyos, aktuális vagy elkerülhetetlen veszély esetén;

- olyan csapások elkerülhetetlensége vagy bekövetkezte esetén, amelyek szükségessé teszik ezek megelőzését, korlátozását vagy következményeinek elhárítását.

3 Alkotmány 73. cikk f-g. pont.

4 Az ostromállapotról, valamint a sürgősségi állapotról szóló 1999. évi 1. sürgősségi kormányrendelet (Ordonanța de urgență nr. 1/1999 privind regimul stării de asediu și regimul stării de urgență) (a továbbiakban: Ostromállapot r.).

5 A fegyveres erők részleges vagy teljes mozgósításának és a hadiállapot rendjéről szóló 2009. évi 355. törvény (Legea nr. 355/2009 privind regimul stării de mobilizare parțială sau totală a forțelor armate și al stării de război) (a továbbiakban: Fegyveres erők tv.).

6 A hivatkozott jogforrások a következők: sürgősségi kormányrendelet, 2004. évi 21. sürgősségi kormányrendelet a Sürgősségi Esetek Menedzsmentjének Nemzeti Rendszeréről; 2001. évi 88. rendelet a katasztrófavédelmi közösségi közszolgálatok alapításáról, szervezéséről és müködéséről; 2015. évi 203. törvény a honvédelem tervezéséről.

7 Vö.: Tanasescu, 2020, 191-192. o. 
Az ostromállapot és a sürgősségi állapot rendjének alapvetô szabályai szerint Románia elnöke elnöki rendelettel (dekrétum) az egész országban vagy egyes területi-közigazgatási egységekben rendelheti el az ostromállapotot vagy a sürgősségi állapotot. ${ }^{8} \mathrm{~A}$ dekrétumot a miniszterelnöknek ellen kell jegyeznie. A dekrétumot azonnal közzéteszik Románia hivatalos közlönyében. ${ }^{9}$ A dekrétum kihirdetését követő legfeljebb öt napon belül Románia elnöke kérelmezi a parlamenttől az intézkedések jóváhagyását. ${ }^{10} \mathrm{Az}$ alkotmány szerint ${ }^{11}$ ha a parlament nem tart ülésszakot, a parlament az ostromállapot vagy a sürgősségi állapot bevezetésétől számított legfeljebb 48 órán belül jog szerint összehívottnak számít, és a bejelentett állapotok egész időtartama alatt müködik. Az ostromállapot és a sürgősségi állapot idején is a parlament a végrehajtó hatalom ellensúlyaként jelenik meg, amely kontrollt gyakorol az államfó dekrétuma ${ }^{12}$ és annak végrehajtása felett is, és alapvető szerepet játszik az intézkedések és az azokat kiváltó okok közötti arányosság fenntartásában. Amennyiben a parlament nem hagyja jóvá az ostromállapotot vagy szükségállapotot, Románia elnöke azonnal visszavonja a dekrétumot, és az elrendelt intézkedések megszúnnek.

Ostromállapotot legfeljebb 60 napra, sürgősségi állapotot legfeljebb 30 napra lehet elrendelni. Parlamenti jóváhagyással az ostromállapot vagy a sürgősségi állapot ezen időkeretek tiszteletben tartásával meghosszabbítható, valamint térben kiterjeszthetô vagy szúkíthetô. Ha az állapot lejárta előtt megszủnik a veszélyhelyzet, akkor dekrétummal és a parlament előzetes jóváhagyásával rendelhető el az állapot visszavonása. Ostromállapot vagy sürgősségi állapot elrendelése és fenntartása csak az ezeket kiváltó okok szerinti mértékben és a Románia által a nemzetközi jog szerint vállalt kötelezettségek tiszteletben tartásával lehetséges. ${ }^{13}$

Az ostromállapot vagy sürgősségi állapot megszúnését követő 60 napon belül Románia elnöke tájékoztatást nyújt a parlamentnek az adott állapot bevezetésének okairól, a foganatosított intézkedésekről és a hasonló helyzetek jövőbeni elkerülésének lehetőségeiről.

A sürgősségi helyzet (situația de urgență) olyan kivételes, nem katonai jellegú esemény, amely méreteinél és intenzitásánál fogva veszélyezteti a lakosság életét és egészségét, a környezetet, fontos anyagi és kulturális értékeket, és a hétköznapi viszonyok helyreállitása érdekében sürgős intézkedések, többletforrások és a bevont eszközök egységes irányítása szükséges.

A riadóállapot (starea de alertă) olyan megelőző és a lakosságot figyelmeztető akciótervek azonnali foganatosítását jelenti, amelyek célja a lakosság életét és egészségét, a környezetet,

8 Lásd a Covid-19 elnöki dekrétumot, amelynek alapját adja az a tény, hogy Romániában a rendszerváltást követően félprezidenciális kormányzati rendszer alakult ki. Erről bővebben lásd:Veress, 2006.

9 A dekrétum kötelező tartalmi elemei a következők: az ostromállapot vagy sürgősségi állapot elrendelésének oka, területe, időtartama, az azonnal foganatosítandó intézkedések, az alapjogok és kötelezettségek nevesítése, amelyek korlátozásra kerülnek, azok a katonai és polgári hatóságok kijelölése, amelyek a dekrétumot végrehajtják és ezek hatáskörei (ostromállapot esetén a központi szereplő a Honvédelmi Minisztérium, sürgősségi állapot idején a Belügyminisztérium), valamint más szükséges rendelkezések.

10 A Covid-19 elnöki dekrétumot a parlament a 2020/3. határozatával hagyta jóvá.

11 Alkotmány 93. cikk.

12 Országgyưlés Hivatala Képviselői Információs Szolgálat, 2016, 37. o.

13 A 2004. évi 453. törvény által bevezetett előírás (Ostromállapot r. 3.1. cikk). 
fontos anyagi és kulturális értékeket veszélyeztető tényezők megelőzése és ezek következményeinek elhárítása.

A mozgósítás vagy hadiállapot esetén a parlament folytatja tevékenységét ezen állapotok teljes idôtartama alatt, vagy ha nincsen ülésszak, akkor a kinyilvánításuktól számított 24 órán belül a jog erejénél fogva összehívottnak számít, ${ }^{14}$ a parlamentet nem lehet feloszlatni mozgósítási, hadiállapot, ostrom- vagy sürgősségi állapot idején, ${ }^{15}$ Románia elnökének mandátuma háború vagy katasztrófa esetén organikus törvénnyel meghosszabbítható. ${ }^{16} \mathrm{Az}$ alkotmány nem módosítható ostromállapot vagy a sürgősségi állapot időtartama alatt, sem pedig háború idején..$^{17}$

A különleges jogrendi esetkörök vonatkozásában fontos a lakosság nemzetvédelmi felkészítéséről szóló jogszabály, ${ }^{18}$ amely a lakosság védelemre való felkészítése, valamint az ország védelmének előkészítése esetén fennálló állampolgári jogok és kötelezettségek meghatározása mellett szabályozza a katonai szolgálatot is, ennek körében pedig rögzíti a katonai szolgálatra kivételes intézkedések idején vonatkozó szabályokat. Ugyancsak tartalmaz külön szabályokat ostromállapot, mozgósítás és háború idejére a katonai szolgálat kapcsán a kötelező katonai szolgálat felfüggesztéséről és az önkéntes katonai szolgálat bevezetéséről szóló törvény. ${ }^{19}$ Ezek tartalma a sorkatonai jogállásról szóló fejezetben kifejtésre kerül. A hadiállapot vonatkozásában jelentôs törvény a Legfelsőbb Honvédelmi Tanácsról szóló törvény, ${ }^{20}$ amely annak szervezete és múködése mellett rögzíti a hatóság kötelezettségeit, hatásköreit is. A különleges jogrendhez kapcsolódóan említésre érdemes a nemzetbiztonsági törvény, ${ }^{21}$ amely szerint az állampolgárok erkölcsi kötelessége a nemzetbiztonság megvalósulásához, ${ }^{22}$ vagyis a társadalmi, gazdasági, politikai stabilitás meglétéhez hozzájárulni. Ezt pedig a törvény szerint - sok más mellett - az állami szuverenitás elleni tevékenység, az ország elleni háború vagy polgárháború provokálása, az állami hatalom gyengítésére irányuló fegyveres cselekmény, valamint a terrorcselekmények fenyegetik. ${ }^{23} \mathrm{~A}$ nemzetbiztonsági szempontból szükséges intézkedések koordinációja pedig a Legfelsőbb Honvédelmi

14 Alkotmány 92. cikk.

15 Alkotmány 89. cikk.

16 Alkotmány 83. cikk.

17 Alkotmány 152. cikk.

18 A lakosság nemzetvédelmi felkészítéséről szóló 2006. évi 446. törvény (Legea nr. 446/2006 privind pregătirea populației pentru apărare).

19 A kötelező katonai szolgálat felfüggesztéséről és az önkéntes katonai szolgálat bevezetéséről szóló 2005 . évi 395. törvény (Legea nr. 395/2005 privind suspendarea pe timp de pace a serviciului militar obligatoriu și trecerea la serviciul militar pe bază de voluntariat).

$20 \mathrm{Az}$ ország Legfelsőbb Honvédelmi Tanácsának szervezetéről és mưködéséről szóló 2002. évi 415. törvény (Legea nr. 415/2002 privind organizarea și funcționarea consiliului suprem de apărare a țării).

21 A nemzetbiztonságról szóló 1991. évi 51. törvény (Legea nr. 51/1991 privind siguranța națională a româniei) 2. cikk (a továbbiakban: Nemzetbiztonsági tv.).

22 Fontos kiemelni a nemzetbiztonsági szempontrendszert arra tekintettel is, hogy több európai állam között Tálas Péter Románia vonatkozásában is helytállóan megállapítja, hogy „[...] a biztonság szubjektív megközelítése, a fenyegetettségpercepció jelentősen elszakadt és távolra került az objektív biztonságtól, a fenyegetettség tényleges mértékétől [...]”. (Tálas, 2016, 43. o.).

23 Nemzetbiztonsági tv. 3. cikk. 
Tanács (Consiliul Suprem de Apărare a Țării) feladata. ${ }^{24}$ Mindezeken túl a különleges jogrendi helyzetek vonatkozásában fontos jogszabályok azok a rendeletek, valamint határozatok, amelyek a kompetenciával rendelkező minisztériumok feladatait határozzák meg. Ezek általában az adott minisztérium szervezeti és múködési szabályait rögzítő jogszabályok.

A különleges jogrendre való felkészülés során a nem honvédelmi tárcák szerepével kapcsolatosan békeidőben megállapítható, hogy az alkotmány alapján a kormány ${ }^{25}$ a végrehajtó hatalom letéteményeseként a parlament által elfogadott kormányzási program szerint biztosítja az ország bel- és külpolitikájának megvalósítását, ellátja a közigazgatás általános vezetését. ${ }^{26}$ Továbbá - ahogyan azt a kormány és a minisztériumok szervezetéről és múködéséről szóló törvény rögzíti - biztosítja a gazdaság és társadalom kiegyensúlyozott müködését és a nemzeti érdekek előmozdítását. ${ }^{27} \mathrm{~A}$ kormányzási program keretében a kormány számos más feladata mellett államhatalmi funkciót gyakorol a közrendi és a nemzetbiztonsági szabályok biztosítása érdekében. ${ }^{28}$ Románia kormánya a miniszterelnökből, helyetteséből és 16 miniszterből áll. ${ }^{29} \mathrm{~A}$ minisztériumok közül - honvédelmi tárcaként - a Nemzetvédelmi Minisztérium felelős elsősorban különleges jogrendi helyzetekben, valamint az arra való felkészülés során az intézkedések koordinálásáért, azonban más tárcák is rendelkeznek kompetenciákkal a különleges jogrend kapcsán. Maga a kormány az erőforrással és infrastruktúrával rendelkezô irányítási és végrehajtási struktúrákat magában foglaló nemzeti mobilizációs rendszer ${ }^{30}$ irányításában múködik közre. ${ }^{31}$

A kormány kapcsán érdemes megemlíteni, hogy a miniszterelnök ellenjegyzése szükséges ahhoz, hogy az elnök kivételes intézkedést rendeljen el. A Nemzetvédelmi Minisztérium mellett a belügyi tárca rendelkezik a különleges jogrend kapcsán komolyabb feladatkörrel. A Belügyminisztérium alapvető feladatai körébe tartozik a terrorizmus, az illegális migráció, valamint a kiberbűnözés elleni harccal kapcsolatos szervezés és végrehajtás, továbbá szakigazgatási szervein keresztül biztosítja a válsághelyzetek civil megelőzési és kezelési képzésének fejlesztését. ${ }^{32}$ A Belügyminisztérium szervezetéről és múködéséről szóló sürgősségi kormányrendelet rögzíti, hogy feladatkörébe tartozik a polgári védelem és a válságkezelés, valamint

24 Nemzetbiztonsági tv. 6. cikk.

25 Romániai kormányzati honlapja: https:/gov.ro/ro/guvernul/cabinetul-de-ministri (Letöltve: 2020. november 16.).

26 Alkotmány 102. cikk.

27 A román kormány és minisztériumok szervezetéről és múködéséről szóló 2001 . évi 90. törvény (Legea nr. 90 din 26 martie 2001 privind organizarea și funcționarea Guvernului României și a ministerelor) (a továbbiakban: Szervezeti tv.) 1. cikk (2) bekezdés.

28 Szervezeti tv. 1. cikk (5) bekezdés.

29 Szervezeti tv. 3. cikk;22/2019. számú bizalmi kormányhatározat (Hotărârea nr. 22 din 4 noiembrie 2019 pentru acordarea încrederii Guvernului).

30 Fegyveres erők tv. 11. cikk.

31 Fegyveres erők tv. 12. cikk.

32 Románia Belügyminisztériumának honlapja: www.mai.gov.ro/despre-noi/atributiile-ministerului-afacerilorinterne/ (Letöltve: 2020. december 12.). 
a határvédelmi rendszer biztosítása.33 (A szakirodalom ugyanakkor azt is megjegyzi, hogy a válságkezelés terén a megyei szervek szintén meghatározó szerepet kapnak.) ${ }^{34}$ Emellett kidolgozza a rendőrség és a közbiztonsági erők békeidőben, sürgősségi helyzetben és háborús helyzetben alkalmazandó stratégiai előírásainak végrehajtását, valamint az államhatárral kapcsolatosan biztosítja a minisztériumok közti koordinációt. ${ }^{35} \mathrm{Az}$ ostromrendelet értelmében az alkotmányos rendet fenyegető veszély esetén elrendelt sürgősségi állapot idején foganatosított intézkedések koordinálása a Belügyminisztérium feladata. ${ }^{36} \mathrm{~A}$ sürgősségi állapot idején katonai rendelet (ordonanță militară) kibocsátására van feljogosítva a belügyminiszter, a helyettese, továbbá az általuk felhatalmazott tisztségviselők attól függően, hogy a rendkívüli állapot az ország egész területére vagy csak egyes közigazgatási egységeire terjed ki. ${ }^{37} \mathrm{~A}$ Belügyminisztérium alá rendelt Vészhelyzeti Főigazgatóság (Inspectoratul General pentru Situaţii de Urgenţă) feladata a különböző veszélyhelyzetek megelőzésére és kezelésére irányuló intézkedések megtétele. Múködése során többek között nyomon követi és értékeli a vészhelyzetek kiváltó okait, tájékoztatja a lakosságot, megelőzô oktatást biztosít számukra, valamint evakuálási intézkedést biztosít személyek és meghatározott áruk veszélyeztetettsége esetén.

A Külügyminisztérium szerepe az államok közötti békés kapcsolatok és együttmûködés fejlesztését célzó nemzetközi kezdeményezésekben való közremúködés, valamint Románia nemzeti érdekeinek nemzetközi színtéren való előmozdítása révén ${ }^{38}$ leginkább a különleges jogrendi esetkörök megelőzésében áll. Az Igazságügyi Minisztérium szervezetéről és múködéséről szóló rendelet a minisztériumi szintű állandó munkaszervezetek között ${ }^{39}$ rendelkezik a Vészhelyzetek Miniszteri Bizottságáról,40 amely miniszteri szintú felhatalmazott szervként válságkezelést támogató szerepet tölt be a válsághelyzetek megelőzése és kezelése során. Tevékenysége során válságkezelési szabályozást dolgoz ki, felméri a válsághelyzeteket, megfelelő intézkedéseket irányoz elő, a szükséges emberi, anyagi és pénzügyi források felhasználását felügyeli, valamint a Vészhelyzeti Főigazgatóságon keresztül informálja a Nemzeti Válságkezelési Bizottságot. ${ }^{41} \mathrm{~A}$ Gazdasági Minisztérium a müködéséről és szervezetéről szóló határozat alapján feladatai ellátása körében biztosítja a katasztrófaelhárítási és polgári védelmi intéz-

33 A Belügyminisztérium szervezetéről és mưködéséről szóló 2007. évi 30. sürgősségi kormányrendelet (Ordonanță de urgență nr. 30 din 25 aprilie 2007 privind organizarea și funcționarea Ministerului Afacerilor Interne) (a továbbiakban: BM kormányrendelet) 1. cikk.

34 Meltzer-Stefanescu-Ozunu, 2018, 2. o.

35 BM kormányrendelet 3. cikk b) pont 5. és 10. alpont.

36 Ostromállapot r. 18. cikk (1) bekezdés.

37 Ostromállapot r. 23. cikk 2. pont.

38 A Külügyminisztérium szervezetéról szóló 16/2017. számú határozat (Hotărârea nr. 16/2017 privind organizarea și funcționarea Ministerului Afacerilor Externe) 1. cikk.

39 Az Igazságügyi Minisztérium szervezetéről és múködéséről szóló rendelet (Regulament din 19 ianuarie 2011 de organizare și funcționare a Ministerului Justiției).

40 Vészhelyzetek Miniszteri Bizottsága (Comitetul ministerial pentru situații de urgență - Ministerial Committee for Emergency Situations).

41 Az Igazságügyi Minisztérium szervezetéról és müködéséről szóló rendelet (Regulament din 19 ianuarie 2011 de organizare și funcționare a Ministerului Justiției) 26-28. cikk. 
kedéseket, a nemzeti és uniós szintû kritikus infrastruktúra meghatározását, kijelölését és védelmét; gazdasági területen javaslatot tesz a Legfelsőbb Honvédelmi Tanácsnak; részt vesz minisztériumközi bizottságok munkájában a nemzetbiztonsággal, vészhelyzetek kezelésével, polgári védelemmel és a kritikus infrastruktúra védelmével kapcsolatos kérdések vonatkozásában. ${ }^{42}$ A Közlekedési és Infrastrukturális Minisztérium tevékenységi körének megfelelően ellátja a veszélyhelyzetek kezelését. ${ }^{43}$ A Regionális Fejlesztési Minisztérium közremúkködik központi és helyi szintû válságkezelési intézkedések kidolgozásában, valamint vészhelyzetek esetén biztosítja az operatív központ szervezését és múködését. ${ }^{44} \mathrm{Az}$ Egészségügyi Minisztériumot vezető miniszter pedig meghozza a járványok, valamint fertőző betegségek által előidézett vészhelyzetek megelőzése, valamint kezelése érdekében szükséges intézkedéseket. ${ }^{45}$

A veszélyhelyzetek alakulásától függően az elnök a parlament hozzájárulásával meghosszabbíthatja a rendkívüli intézkedés idôtartamát, valamint kiterjesztheti vagy korlátozhatja annak hatályát. Főszabály szerint az ostromállapot, valamint a sürgősségi állapot az elrendelésről vagy a meghosszabbításról szóló rendeletben meghatározott időpontban szúnik meg, azonban az elrendelésre okot adó helyzet idő előtti megszúnése esetén rendeletben megszüntethető a kivételes intézkedés. ${ }^{46}$ Ahogy azt már említettük, kivételes intézkedések során katonai rendeletek bocsáthatók ki, amelyek rendelkezéseinek megsértése polgári jogi, szabálysértési vagy büntetőjogi felelősséget von maga után. ${ }^{47} \mathrm{~A}$ katonai rendelet kibocsátására jogosultak meghatározása ostromállapot és sürgősségi állapot esetén is azon múlik, hogy az ország egész területére vagy csak meghatározott részére terjed-e ki. Az ország egész területére elrendelt ostromállapot esetén a honvédelmi miniszter vagy a vezérkari fönök, egyes körzeteknél pedig az érintett területi egységek parancsnokai jogosultak katonai rendelet kiadására. Sürgősségi állapot esetén pedig az ország egész területére elrendelt kivételes intézkedés kapcsán a belügyminiszter vagy helyettese, az egyes területekre elrendelt kivételes intézkedés kapcsán a megyei rendőrségi főfelügyelők, ha pedig a sürgősségi állapotot két vagy több megyére rendelték el, a helyettes által felhatalmazott egyéb tisztviselók jogosultak katonai rendelet kiadására. ${ }^{48}$ Azonban az ostromállapot és a sürgősségi állapot idején is csak szükség esetén, az elrendelés alapjául szolgáló helyzettel ará-

42 A Gazdasági Minisztérium múködéséről és szervezetéről szóló 27/2017. számú határozat (Hotărârea nr. 27/2017 privind organizarea și funcționarea ministerului economiei) 4. cikk.

43 A Közlekedési Minisztérium szervezetéról és müködéséről szóló 21/2015. számú határozat (Hotărârea nr. 21 din 14 ianuarie 2015 privind organizarea și funcționarea Ministerului Transporturilor) 2. cikk 43. pont.

44 A Regionális Fejlesztési és Közigazgatási Minisztérium szervezetéről és múködéséről szóló 51/2018. számú határozat (Hotărârea nr. 51 din 15 februarie 2018 privind organizarea și funcționarea Ministerului Dezvoltării Regionale și Administrației Publice) 5. cikk 59. és 98. pont.

$45 \mathrm{Az}$ egészségügyi reformról szóló 2006. évi 95. törvény (Legea nr. 95 din 14 aprilie 2006 privind reforma în domeniul sănătății) 25. cikk (2) bekezdés.

46 Ostromállapot r. 15-16. cikk.

47 Ostromállapot r. 27. cikk.

48 Ostromállapot r. 23. cikk. 
nyosan, az igazságügyi miniszter egyetértésével korlátozható az alapvető jogok és szabadságok gyakorlása. ${ }^{49}$

Ahogy arról már szó esett a korábbiakban, az alkotmányban egy másik, honvédelmi feladatokat megfogalmazó szakasz értelmében az ország elleni fegyveres támadás esetén Románia elnöke intézkedéseket foganatosíthat a támadás visszaverésére. Mindezeket pedig késedelem nélkül a parlament tudomására hozza. Abban az esetben, ha a parlament nem tart ülésszakot, az agresszió kirobbanásától számított 24 órán belül jogilag összehívottnak számít. Mozgósítás vagy hadiállapot esetén pedig a parlament folytatja tevékenységét ezen állapotok teljes időtartama alatt, vagy ha nincsen ülésszak, akkor a kinyilvánításuktól számított 24 órán belül jogilag összehívottnak kell tekinteni. ${ }^{50} \mathrm{~A}$ fegyveres erők mozgósításáról és a hadiállapotról önálló törvény rendelkezik. A mozgósítás a különféle politikai, gazdasági, társadalmi, közigazgatási, diplomáciai, jogi és katonai területeket érintő intézkedések békeidőben történő kidolgozását, előkészítését, valamint ezeknek az állam szuverenitását, integritását, demokratikus alapelveit támadó komoly fenyegetettség esetén való alkalmazását foglalja magában. ${ }^{51} \mathrm{~A}$ hadiállapot pedig azon rendkívüli intézkedések összessége, amelyeket az állam önvédelmi joga gyakorlása érdekében alkalmazhat, leginkább politikai, gazdasági, társadalmi, közigazgatási, diplomáciai, jogi és katonai területeken. ${ }^{52} \mathrm{~A}$ mozgósítás lehet részleges vagy teljes, attól függően, hogy az állam, valamint az apparátus egészét érinti-e..$^{53}$ Mind a mozgósítás, mind pedig a hadiállapot során az alapvető jogok kizárólag az alkotmánnyal összhangban korlátozhatók..$^{54}$ A mozgósítás, valamint a hadiállapot elrendelése az alkotmány rendelkezései alapján történik. Mindez az elnök és a parlament együttmúködését feltételezi, ugyanis Románia elnökének a mobilizálásra és háborús helyzetre vonatkozó rendeletét a parlament hagyja jóvá vagy utasítja el. ${ }^{55} \mathrm{~A}$ nemzeti mozgósítási rendszer - amely az irányítási és végrehajtási szervezeten túl magában foglalja a kapcsolódó infrastruktúrát és az erőforrásokat - irányítása a parlament, az elnök, a Legfelsőbb Honvédelmi Tanács, a kormány és más állami szervek feladatkörébe tartozik.

Megkerülhetetlen intézmény a Legfelsőbb Honvédelmi Tanács, amely autonóm közigazgatási hatóságként egységesen megszervezi és egybehangolja az ország védelmével és a nemzetbiztonsággal, a nemzetközi biztonság fenntartásában, a katonai szövetségeken belüli kollektív védelemben, valamint a béke fenntartásával vagy visszaállításával kapcsolatos kezdeményezésekben való részvétellel összefüggő tevékenységeket. ${ }^{56} \mathrm{~A}$ Legfelsőbb Honvédelmi Tanácsról szóló törvény alapján a Legfelsőbb Honvédelmi Tanács javaslatot tesz Románia

49 Ostromállapot r. 4. cikk.

50 Alkotmány 92 . cikk.

51 Fegyveres erók tv. 1. cikk.

52 Fegyveres erók tv. 2. cikk.

53 Fegyveres erők tv. 3. cikk.

54 Fegyveres erók tv. 4. cikk.

55 Fegyveres erők tv. 5-7. cikk.

56 Alkotmány 119. cikk. 
nemzetbiztonsági és katonai stratégiájával kapcsolatban, valamint elnöki kérésre javaslatot tesz és elemzést végez az ostromállapot és sürgősségi állapot elrendelése, a fegyveres erők mozgósítása, az országgal szembeni fegyveres támadás elleni fellépés, valamint hadiállapot kihirdetése kapcsán..$^{57}$

Az alkotmány rendelkezik a honvédelem terén lévő feladatokról, amely szerint Románia elnöke a fegyveres erôk parancsnoka, és ellátja a Legfelsőbb Honvédelmi Tanács elnökének tisztségét. ${ }^{58} \mathrm{~A}$ parlament előzetes jóváhagyásával kihirdetheti a fegyveres erők részleges vagy általános mozgósítását. Csakis rendkívüli esetekben az elnök döntését utólagosan kell jóváhagyásra a parlament elé terjeszteni a döntés meghozatalától számított legfeljebb öt napon belül. Az ország elleni fegyveres támadás esetén Románia elnöke intézkedéseket foganatosít a támadás visszaverésére, és ezeket késedelem nélkül a parlament tudomására hozza. Ha a parlament nem tart ülésszakot, akkor a jog erejénél fogva öszszehívottnak tekintendő az agresszió kirobbanásától számított 24 órán belül.59 Mozgósítás vagy hadiállapot esetén a parlament folytatja tevékenységét ezen állapotok teljes időtartama alatt, vagy ha nincsen ülésszak, akkor a kinyilvánításuktól számított 24 órán belül a jog szerint összehívottnak számít. A kivételes intézkedések vonatkozásában Románia elnökének jogosítványai elég hangsúlyosak, de a parlament ellenőrző szerepe elméletileg nem szúnik meg. A honvédelmi törvény szerint a honvédelmi kérdésekben az elnök dönt országgyúlési felhatalmazással. Háború idején a Legfelsőbb Honvédelmi Tanács hozza a döntéseket, tájékoztatási kötelezettséggel tartozik a parlamentnek, amelynek a hadiállapot bejelentése után legkésőbb 24 órával össze kell ülnie, és ez így is marad a háborús helyzet végéig (24 órás időhatár csak az alkotmányban szerepel). A hadsereg főparancsnoksága felel a mûveletekért, valamint a katonai akciók irányítója békeidőben és válsághelyzetekben (Válsághelyzetek Központja). Békében, válsághelyzetekben és háborúban a Nemzetvédelmi Minisztérium élén álló miniszter képviseli a minisztériumot a többi minisztériummal és kormányzati szervvel, illetve az egyéb közigazgatási hatóságokkal szemben, valamint az együttmúködést is koordinálja.

\section{Az alapjogok korlátozásával kapcsolatos kérdések}

A Románia alkotmányában található alapjog-korlátozási szabályoknak két szintje különíthető el. Az alkotmány tartalmazza az általános alapjog-korlátozási klauzulát, amely szerint egyes jogok vagy szabadságok gyakorlása kizárólag törvénnyel korlátozható, ha ezt

57 Az ország Legfelsőbb Honvédelmi Tanácsának szervezetéról és múködéséről szóló 2002. évi 415. törvény (Legea nr. 415/2002 privind organizarea și funcționarea consiliului suprem de apărare a țării) 4 . cikk.

58 Alkotmány 92. cikk.

59 Országgyưlés Hivatala Közgyưjteményi és Közművelődési Igazgatóság Képviselői Információs Szolgálat, 2016, 36-37. o. 
adott esetben a nemzetbiztonságnak, a közrendnek, a közegészségnek vagy a közerkölcsnek, az állampolgárok jogainak és szabadságjogainak a védelme, a büntetőljárás lefolytatása, valamely természeti csapás vagy rendkívül súlyos katasztrófa következményeinek megelőzése megköveteli. ${ }^{60}$ Továbbá elôírja, hogy ezt a korlátozást csak akkor lehet elrendelni, ha az szükséges. Az intézkedésnek arányosnak kell lennie a kiváltó helyzettel, és diszkriminációmentes módon, a jog vagy szabadság létének csorbítása nélkül kell a korlátozást alkalmazni.

Az általános alapjog-korlátozási klauzulából levezethető alkotmányjogi feltételrendszer összefoglalva a következő:

1. Az alapjog vagy alapszabadság korlátozásának kizárólagos eszköze a törvény. A román alkotmányos rend lehetôvé teszi a kormánynak, hogy törvényi szintú szabályozást alkosson meg azokban a rendkívüli esetekben, amelyeknek szabályozása nem tû́r késedelmet (úgynevezett sürgősségi kormányrendelet [ordonanţe de urgenţă]). A sürgősségi kormányrendelet a közzétételével hatályba lép, viszont utólag a parlamentnek jóvá kell hagynia. A parlament az ilyen rendeletet változtatás nélkül jóváhagyhatja, módosításokkal fogadhatja el vagy elutasíthatja. Kérdésként felmerül, hogy az alapjog vagy alapszabadság korlátozása sürgősségi kormányrendelettel megtörténhet-e. A kérdést a 2003. évi alkotmánymódosítás oldotta meg, ekkor került az alkotmányba ${ }^{61}$ az az elő́rás, amely szerint sürgősségi kormányrendeleteket nem lehet elfogadni az alkotmányos törvények területén, ezek nem érinthetik az állam alapvetố intézményeinek a jogállását, az alkotmányban előírt jogokat, szabadságokat és kötelezettségeket, a választási jogokat, és nem rendelhetnek el egyes javaknak a köztulajdonba való átvételérôl szóló kényszerintézkedéseket. Következésképpen az a sürgősségi kormányrendelet, amely az alkotmányban elốrt jogokat vagy szabadságokat (alapjogok vagy alapszabadságok) korlátozza, alkotmányellenes. Az alkotmánymódosítás előtt elfogadott törvényerejû́ rendeleti normákat is elismerték alapjog vagy alapszabadság korlátozására alkalmas eszköznek. ${ }^{62}$ Így kialakult a törvényerejû́ kormányrendeletek két csoportja:

- az alkotmánymódosítás után elfogadott kormányrendeletek esetén nem lehetséges az alapjog törvényerejû̉ kormányrendelet révén történő korlátozása;

— az alkotmánymódosítás előtt elfogadott, alapjogot vagy alapszabadságot korlátozó törvényerejû̉ kormányrendeletek viszont alkotmányos módon tartalmazhatnak alapjog- vagy alapszabadság-korlátozást. ${ }^{63}$

2. Az alapjog vagy alapszabadság korlátozásának indoka a nemzetbiztonságnak, a közrendnek, a közegészségnek vagy a közerkölcsnek, az állampolgárok jogainak és szabadságjogainak a védelme, a büntetőeljárás lefolytatása, valamely természeti csapás vagy valamely

60 Alkotmány 53. cikk.

61 Alkotmány 115. cikk.

62 A román alkotmánybíróság döntéseket (decizii) fogad el az alkotmányossági kérdések vizsgálata során, ezért az alkotmánybírósági döntések kifejezést röviden ABD-ként jelöljük (1994/75. ABD, 1994/139. ABD).

$632005 / 148$. ABD. 
rendkívül súlyos katasztrófa következményeinek megelőzése lehet. Idekapcsolódik, hogy két jogszabály alkotmányosságát megállapították, mert korlátozzák ugyan az információhoz való hozzáférést, de a korlátozásokat a nemzetbiztonság érdekében törvényben foganatosítják az alkotmány keretei között. ${ }^{64} \mathrm{~A}$ nemzetbiztonság fogalmának egyébként az alkotmánybíróság értelmezése szerint gazdasági tartalma is van: a román állam makrogazdasági és pénzügyi stabilitása nemzetbiztonsági kérdés. ${ }^{65}$

3. A korlátozás mértékét illetően pedig az alkotmány általános követelményként támasztja azt, hogy a korlátozás csak akkor alkotmányos, amennyiben megfelel a következő kritériumoknak:

- a demokratikus társadalomban a korlátozás szükséges (ide sorolta be az alkotmánybíróság gyakorlata, hogy a korlátozásnak szükségszerủen időlegesnek kell lennie); ${ }^{66}$

- a korlátozás arányos az azt kiváltó helyzettel;

- a korlátozást diszkriminációmentesen alkalmazzák;

- a korlátozás nem érintheti az alapjog vagy az alapszabadság létét, következésképpen csak az alapjog vagy alapszabadság gyakorlása korlátozható.

Az alkotmányban foglaltakból ${ }^{67}$ még egy kapcsolódó korlát következik: az alapjogok és alapszabadságok vagy ezek biztosítékai alkotmánymódosítással sem szüntethetők meg, következésképpen az alkotmánymódosító törvény is lehet alkotmányellenes, amennyiben alapjogokat vagy alapszabadságokat csorbítana. ${ }^{68}$

Az alkotmánybíróság gyakorlata pontosította, hogy a korlátozásnak ez a feltételrendszere csakis az alapjogokra és alapszabadságokra és nem bármilyen alanyi jogra vonatkozik. Így nem minősül alapjognak vagy alapszabadságnak például: bármilyen súlyú teher szállítása a közutakon; ${ }^{69}$ a fizetésképtelen adós tevékenysége; ${ }^{70}$ valaki a szabadsága előtt többlet távolléti díjat kapjon, ugyanis ebben az esetben külön törvény által alapított alanyi jogról és nem alapjogról van szó, ${ }^{71}$ ezzel szemben a fizetéshez való jog alapjog, a fizetések költségvetési törvénnyel való felfüggesztése, elhalasztása az alkotmány feltételrendszerének ${ }^{72}$ tiszteletben tartása nélkül alkotmányellenes; ${ }^{73}$ az éhségsztrájk nem alapjog, ezért korlátozható; ${ }^{74}$ a közös tulajdon szabályozásából fakadó korlátozások sem jelentenek alapjog-korlátozást. ${ }^{75}$

64 Alkotmány 53. cikk, 2006/766. ABD.

65 2006/855. ABD.

66 1994/75. ABD, 1994/139. ABD, 1992/6. ABD.

67 Alkotmány 152 . cikk.

68 Alkotmány 152 . cikk.

69 2004/11. ABD.

70 2001/223. ABD.

71 2005/214. ABD.

72 Alkotmány 53. cikk.

73 2005/148. ABD.

74 1999/13. ABD.

75 1999/237. ABD. 
Az alkotmányos alapjog-korlátozás másik szintje az egyes alapjogok és alapszabadságok nevesített korlátozása. Az alkotmány számos alapjog esetén kifejezetten utal a korlátozás lehetőségére.

Az előzőeken túl az alkotmány több alapjog esetén is kifejezetten utal arra, hogy annak gyakorlása, biztosítása a törvényben meghatározott keretek között vagy a törvény feltételei szerint lehetséges. Fontos leszögezni, hogy azok az esetek, amikor maga az alkotmány szövege további törvényi szabályozásban ismeri el azt a lehetőséget, hogy a jogalkotó határozza meg az alapjog vagy alapszabadság gyakorlásának a feltételeit, ${ }^{76}$ akkor nem kell vizsgálni az általános korlátozási klauzula által megállapított feltételrendszert, hiszen a klauzula általános normának minősül, amelyhez képest az egyes alapjogra vagy alapszabadságra vonatkozó előírások, ideértve a korlátozások lehetőségét is, előnyt élveznek. Nyilván fenn kell állnia az összhangnak az egyes alapjogra vagy alapszabadságra vonatkozó alkotmányos szabályok és a törvényes részletező, a jog gyakorlásának feltételeit és korlátait meghatározó törvényi szintű szabályozás között.

Az ostromállapot és a sürgősségi állapot idején az alapjog-korlátozásra közös szabályok vonatkoznak, amelyek szerint az ostromállapot és sürgósségi állapot idején tilos:

- az élethez való jog korlátozása, kivéve, amikor a haláleset a háborús jog tiszteletben tartásával foganatosított cselekmény következménye;

- a kínzás, valamint az embertelen vagy megalázó bánásmód;

- a nemzeti vagy nemzetközi jog szerint bűncselekménynek nem minősített tettért való elítélés;

— az igazságszolgáltatáshoz való szabad hozzáférés jogának korlátozása.

A normából egyértelműen következik, hogy ezek az alapjogok sem az ostromállapot, sem a sürgősségi állapot idején nem korlátozhatók. Ostromállapot és sürgősségi állapot idején tehát bizonyos alapjogok és alapszabadságok korlátozása lehetséges, a fent tárgyalt kivételek tiszteletben tartása mellett és az alkotmányban foglalt feltételek szerint. ${ }^{77}$ Fontos itt leszögezni, hogy a jogszabály eredeti szövege általánosan lehetővé tette az alapjog-kor-

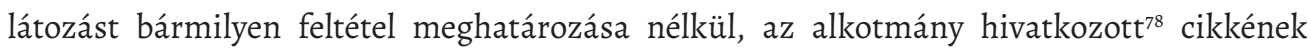

76 Például a táblázatban is bemutatott esetben az alkotmány 25. cikke szerint a belföldi és a külföldi mozgásszabadság garantált, de e jog gyakorlásának a feltételeit törvény állapítja meg; hasonlóképpen a közigazgatási bíráskodás esetében a hatóság által jogában vagy törvényes érdekében sértett személy bírósághoz való fordulásának a jogát törvény korlátozhatja. Így például a közigazgatási bíráskodásról szóló 2004. évi 554. törvény kivonja a bírósági kontroll alól a katonai aktusokat és a hatóságoknak a parlamenttel való kapcsolataik vonatkozásában kibocsátott aktusait (5. cikk).

77 Alkotmány 53. cikk.

78 Alkotmány 53. cikk. 
teljes figyelmen kívül hagyásával.79 Ostromállapot vagy sürgősségi állapot idején nem kell alkalmazni a közigazgatási döntéshozatal átláthatóságára és a társadalmi egyeztetésre vonatkozó szabályokat azon jogszabálytervezetek esetén, amelyek ezen állapotok bevezetésének a következményei. ${ }^{80}$

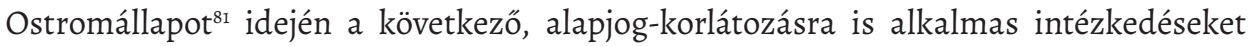
lehet foganatosítani:

— országhatár lezárása vagy az ellenőrzés intenzitásának növelése;

— katonai célú termékek előállításával foglalkozó vállalatok termelési tevékenységének fokozása;

- a katonai célú fuvarozás elsőbbségének biztosítása;

- javak elkobzása.

Sürgősségi állapot idején a következő, alapjog-korlátozásra is alkalmas intézkedéseket lehet foganatosítani:

- a védelmi célú fuvarozás elsőbbségének biztosítása;

— országhatár lezárása vagy az ellenőrzés intenzitásának növelése;

- javak elkobzása.

Sürgősségi állapot idején a hatóságok, közintézmények, vállalkozások és a lakosság köteles a vonatkozó jogszabályok alkalmazására és az elrendelt intézkedések tiszteletben tartására.

79 A vonatkozó jogszabályi szöveg eredeti változata: „Ostromállapot és sürgősségi állapot idején az elrendelésüket kiváltó okok súlyosságával arányosan, és kizárólag, amennyiben ez szükséges, az Alkotmányban elöírt alapjogok és szabadságok az igazságügyi miniszter beleegyezésével korlátozhatók." Ezt az alkotmánysértő állapotot a 2004. évi 453. törvény szüntette meg.

80 A 2020. évi 34. sürgősségi kormányrendelet által bevezetett elöírás.

$81 \mathrm{Az}$ Ostromállapot r. 20. cikke szerint a katonai és polgári hatóságok jogosultak: a lakosságnál található túzfegyverek és robbanóanyagok kötelező időszakos letétét elrendelni; a mozgásszabadságot korlátozni; ellenőrizni, razziákat foganatosítani; gyülekezési jogot korlátozni, tüntetéseket, felvonulásokat engedélyezni vagy megtiltani; az ostromállapottal vagy sürgősségi állapottal érintett helyszínekről bármely személyt, akinek a jelenléte nem indokolt, eltávolítani; az eltávolított vagy menekült személyeket nyilvántartani és irányítani; az ostromállapotra vagy sürgősségi állapotra vonatkozó információkat, a természeti katasztrófák kivételével, csak a katonai hatóságok engedélyével lehet nyilvánosságra hozni; az audiovizuális és a nyomtatott sajtó elsőbbséggel köteles a katonai hatóságok hirdetményeit közzétenni; ideiglenesen elrendelhetik üzemanyag-töltóállomások, vendéglátóipari létesítmények, egyesületi székhelyek vagy más nyilvános helyek bezárását; ideiglenesen elrendelhetik nyomtatott sajtótermékek terjesztésének tilalmát, vagy rádió-, valamint televíziós músorok sugárzását megtilthatják; különböző létesítmények katonai őrzését rendelhetik el; élelmiszer és más alapvető áruk racionalizálására vonatkozó intézkedéseket foganatosíthatnak; katonai rendeleteket fogadhatnak el az ostromállapotot vagy szükségállapotot elrendelő dekrétum feltételei szerint; a közúti, vasúti, tengeri, folyami és légi közlekedést megtilthatják; tartalékos katonákat mozgósíthatnak, és elrendelhetik a munkaképes természetes személyek közérdekű munkavégzését. 


\begin{tabular}{|c|c|}
\hline & A korlátozó rendelkezés tartalma \\
\hline Élethez való jog & $\begin{array}{l}\text { A haláleset a háborús jog tiszteletben tartásával foganatosított cse- } \\
\text { lekmény következménye. }\end{array}$ \\
\hline \multirow{4}{*}{ Magántulajdon } & $\begin{array}{l}\text { A lakosságnál található fegyverek és robbanóanyagok kötelező idő- } \\
\text { szakos letéte. }\end{array}$ \\
\hline & $\begin{array}{l}\text { Élelmiszer és más alapvetô áruk racionalizálására vonatkozó intézke- } \\
\text { déseket foganatosíthatnak. }\end{array}$ \\
\hline & Javak elkobzása. \\
\hline & Különböző létesítmények katonai őrzését rendelhetik el. \\
\hline Kényszermunka tilalma & $\begin{array}{l}\text { Tartalékos katonákat mozgósíthatnak, és elrendelhetik a munkára } \\
\text { alkalmas természetes személyek közérdekú munkavégzését. }\end{array}$ \\
\hline \multirow{6}{*}{ Mozgásszabadság } & Személyek és járművek szabad mozgásának korlátozása. \\
\hline & $\begin{array}{l}\text { Az ostromállapottal vagy sürgősségi állapottal érintett helyszínekről } \\
\text { bármely személyt, akinek a jelenléte nem indokolt, el lehet távolítani. }\end{array}$ \\
\hline & Az eltávolított vagy menekült személyek nyilvántartása és irányítása. \\
\hline & $\begin{array}{l}\text { Ideiglenesen elrendelhetik üzemanyag-töltőállomások, vendéglátó- } \\
\text { ipari létesítmények, egyesületi székhelyek vagy más nyilvános helyek } \\
\text { lezárását. }\end{array}$ \\
\hline & A közúti, vasúti, tengeri, folyami és légi közlekedést megtilthatják. \\
\hline & Országhatár lezárása vagy az ellenőrzés intenzitásának növelése. \\
\hline $\begin{array}{c}\text { Lakóhely, tartózkodási hely } \\
\text { sérthetetlensége }\end{array}$ & Személyek és helyek ellenőrzése, razziák foganatosítása. \\
\hline Gyülekezési szabadság & $\begin{array}{l}\text { Gyülekezési jog korlátozása, tüntetések, felvonulások engedélyezése } \\
\text { vagy megtiltása. }\end{array}$ \\
\hline \multirow{3}{*}{$\begin{array}{l}\text { Kifejezés (szólás, vélemény- } \\
\text { nyilvánítás) szabadsága }\end{array}$} & $\begin{array}{l}\text { Az ostromállapotra vagy sürgősségi állapotra vonatkozó informá- } \\
\text { ciókat, a természeti katasztrófák kivételével, csak a katonai ható- } \\
\text { ságok engedélyével lehet nyilvánosságra hozni. }\end{array}$ \\
\hline & $\begin{array}{l}\text { Az audiovizuális és a nyomtatott sajtó elsőbbséggel köteles a katonai } \\
\text { hatóságok hirdetményeit közzétenni. }\end{array}$ \\
\hline & $\begin{array}{l}\text { Ideiglenesen elrendelhetik nyomtatott sajtótermékek terjeszté- } \\
\text { sének tilalmát, vagy rádió-, valamint televíziós músorok sugárzását } \\
\text { megtilthatják. }\end{array}$ \\
\hline Gazdasági szabadság & $\begin{array}{l}\text { Katonai célú termékek előállításával foglalkozó vállalatok termelési } \\
\text { tevékenységének fokozása. }\end{array}$ \\
\hline
\end{tabular}


A sürgősségi helyzetre és a riadóállapotra vonatkozó szabályozások ${ }^{82}$ nem tartalmaznak az alapjogok és alapszabadságok korlátozására vonatkozó rendelkezéseket, azonban a szabályozás elöírja, hogy a különleges jogrendi helyzetek kezelése kizárólag az alapjogok és alapszabadságok tiszteletben tartásával valósítható meg. Következésképpen, ha a veszélyhelyzet alapjog-korlátozást tesz szükségessé, akkor az ostromállapot vagy sürgősségi állapot kihirdetése szükséges, ezzel szemben a sürgősségi helyzet és a riadóállapot nem tesz lehetôvé alapjog-korlátozást. A szabályozás nem tér ki külön az egészségügyi veszélyhelyzetre, mert a román jogalkotó az egészségügyi veszélyhelyzet kezelésére a riadóállapot jogintézményét tartja megfelelőnek (lásd ezzel kapcsolatban a következő alfejezetet). Az állami egészségügyi intézményrendszer feladatai között szerepel a járványhelyzetek megelőzése és a járványügyi riadóállapot elrendelése és a járványok ellenőrzése, de a járványok által kiváltott sürgősségi helyzetekre vonatkozó intézkedéseket a törvény miniszteri rendelet szabályozási körébe utalja. ${ }^{83}$ Egyetlen törvényes rendelkezés van, amit még érdemes megemlíteni: az állami hatóságok járvány idején jóváhagyhatják nem engedélyezett gyógyszerek alkalmazását is. ${ }^{84}$

Alkotmányjogi szempontból érdekes, hogyan múködnek a gyakorlatban a fenti rendelkezések. Az Ostromállapot $r$. járványügyi veszélyhelyzet kezelésére nem alkalmas. Megalkotására az alkotmány elfogadásához képest megkésve került sor, és tartalmát a „bányászjárások" ${ }^{\prime 5}$ történelmi tapasztalata formálta. Ahogy korábban már említettük, az Ostromállapot r. kifejezett előírást tartalmaz arra vonatkozóan, hogy az alapjogok korlátozása az alkotmány ${ }^{86}$ szerint történhet, mégpedig úgy, hogy a korlátozás kizárólagos eszköze a törvény, vagyis a korlátozás kizárólagos parlamenti hatáskör. Ezt a megközelítést részben lazíthatja, hogy az Ostromállapot $r$. törvényerejú jogszabály, és ez a rendelet valóban tartalmazza bizonyos alapjogok korlátozásának a lehetőségét. Tehát a helyzet értelmezhető úgy, hogy a korlátozás törvényi szintje (elvi lehetősége) a törvényerejû kormányrendelet révén teljesül,

82 A Sürgősségi Esetek Menedzsmentjének Nemzeti Rendszeréről szóló 2004. évi 21. sürgősségi kormányrendelet (Ordonanța de urgență nr. 21 din 15 aprilie 2004 privind Sistemul Național de Management al Situațiilor de Urgență), valamint a katasztrófavédelmi közösségi közszolgálatok alapításáról, szervezéséről és müködéséről szóló 2001. évi 88. kormányrendelet (Ordonanța nr. 88 din 30 august 2001 privind înființarea, organizarea și funcționarea serviciilor publice comunitare pentru situații de urgență).

$83 \mathrm{Az}$ egészségügy reformjáról szóló 2006. évi 95. törvény (Legea nr. 95 din 14 aprilie 2006 privind reforma în domeniul sănătății) (a továbbiakban: Eü. reform tv.) 5-6. és 25. cikk.

84 Eü. reform tv. 703. cikk.

85 Romániában a rendszerváltás után a posztkommunista politikai hatalom az ellenzéki mozgalmakkal szemben vetette be a Zsil-völgyi bányászokat 1990-ben. Az 1977-es Zsil-völgyi, szociális követelésekre alapuló, de rendszerellenes potenciállal rendelkező bányászmozgalom után a kommunista titkosszolgálatok beépültek a helyi bányászati vezetők közé. Főleg ennek köszönhetően lehetett őket Bukarestbe hívni az ellenzéki mozgalmak szétverésére. 1999 januárjában és februárjában két bányászjárásra is sor került, amikor a bányászok szociális követeléseket fogalmaztak meg, valamint az 1990. évi bányászjárásban betöltött szerepéért börtönbüntetésre ítélt bányászvezér, Miron Cozma elítélése ellen tüntettek. A bányászok ellen karhatalmi erőket kellett bevetni, és a szabályozás erre a történelmi tapasztalatra épül.

86 Alkotmány 53. cikk. 
a dekrétum csak konkretizálja, a helyzetre szabja az e törvényi elöirások szerinti konkrét korlátozásokat. ${ }^{87}$

A Covid-19-világjárvány következtében elrendelt sürgősségi állapotról szóló 2020. évi 195. elnöki dekrétum ${ }^{88}$ (a továbbiakban: Covid-19 elnöki dekrétum) tételesen felsorolja a korlátozásra kerülő alapjogokat: a szabad mozgás jogát, a családi és a magánélet jogát, a lakhely sérthetetlenségét, az oktatáshoz való jogot, a gyülekezési szabadságot, a magántulajdonjogot, a sztrájkjogot és a gazdasági szabadságot korlátozza a dekrétum, azonban ezek között olyan jogok is szerepelnek (például az oktatáshoz való jog), amelynek korlátozására az Ostromállapot r. nem teremt jogalapot (elvi szinten sem szabályozza az oktatáshoz való jog korlátozásának a lehetőségét). A Velencei Bizottság megállapítása szerint a kormány intézkedésének minősül e dekrétum kiadása. ${ }^{89}$ A Covid-19 elnöki dekrétum viszont elrendeli, hogy a sürgősségi állapot idejére valamennyi oktatási intézmény szüneteltesse a tevékenységét.90 Az is kétségtelen, hogy az elnöki dekrétumot jóváhagyó 2020/3. parlamenti határozat nem törvény, és a dekrétumot sem emeli törvényi rangra, tehát Romániában aggályos az alkotmány ${ }^{91}$ alapján a dekrétum által bevezetett alapjog-korlátozások alkotmányossága, különösen azon alapjogok és alapszabadságok tekintetében, ahol a korlátozás lehetőségére nem utal a törvényi szintú szabályozás, azaz az Ostromállapot r. Ellentétes szakmai álláspontot is megfogalmaztak, amely szerint az államfó diszkrecionálisan korlátozhatja az alapjogokat és alapszabadságokat, köszönhetően az utólagos parlamenti kontrollnak, ${ }^{92}$ vagyis ezen álláspont szerint az ostromállapotot vagy sürgősségi állapotot elrendelő dekrétum utólagos parlamenti jóváhagyása teljesíti az alkotmány elvárásait.93 Az érvelés inkább az egész jogi felépítmény múködőképességének a biztosítását szolgálja, mert a szabályozás logikai egységének vizsgálata és az alkotmányos kritériumok következetes alkalmazása nem erre az értelmezési eredményre vezet. Sôt, az alapjogok és alapszabadságok korlátozásának legalsó szintje a katonai rendeletek köre (amelyeket a belügyminiszter bocsátott ki és a miniszter-

87 Itt válik fontossá az a probléma, amiről már volt szó: a 2003. évi alkotmánymódosítás megtiltotta, hogy alapjogot vagy alapszabadságot törvényerejû́ kormányrendelettel korlátozzanak, de a korábbi, így például az 1999-ben elfogadott korlátozások hatályosak maradtak.

88 Decret nr. 195 din 16 martie 2020 privind instituirea stării de urgență pe teritoriul României.

89 Venice Commission, 2020, 13. o.

90 A Covid-19 elnöki dekrétum 49. cikk.

91 Alkotmány 53. cikk.

92 Apostol Tofan, 2014, 148. o.

93 Alkotmány 53. cikk. 
elnök ellenjegyzett), és amelyek szintén fontos korlátozásokat vezettek be a Covid-19 elnöki dekrétum alapján. ${ }^{44}$

Következésképpen az ostromállapot és a sürgősségi állapot törvényi szintú szabályozása és a szabályok gyakorlati alkalmazása jogállami kritériumok alapján nem problémamentes, elsősorban azért, mert az Ostromállapot r.-be foglalt szabályozás pontatlan és elégtelen. Az Ostromállapot r.-ben világosan meg kellett volna szabni a korlátozható jogokat és a korlátozás maximális mértékét, külön az ostromállapot, külön a sürgősségi állapot esetére, hogy azt az elnöki dekrétum konkretizálhassa, tehát törvényi úton megállapított tartalmú különleges jogrendet rendelhessen el. A jelenlegi gyakorlat így jogállami mércék mentén aggályos, és nincs összhangban a hatályos alkotmány elvárásaival.

Szintén aggályos, mert az alapjogok és alapszabadságok korlátozását is tartalmazza, hogy a katonaság állományának jogállásáról, valamint a rendőrök jogállásáról szóló jogszabályokat sürgősségi kormányrendelettel módosították, e törvényerejú kormányrendelet $^{95}$ egyes előírásai ellentétesek az alkotmánnyal, ${ }^{96}$ mert alapjog-korlátozó jellegúek, és így csakis törvényi formában lehetett volna elfogadni ezeket, például a fizetett vagy fizetés nélküli szabadságok felfüggesztésének vagy kötelező elrendelésének joga a munka szociális védelmére vonatkozó alapjogba ütközik. ${ }^{97}$ Amíg például a szabadságról való visszahívás valóban indokolt lehet az ostromállapotban vagy a sürgősségi állapotban, ennek jogi alapját az alkotmány ${ }^{98}$ alapján akkor is törvénynek és nem sürgősségi kormányrendeletnek kellene biztosítania. A törvényerejû́ rendelet egyébként a szabályozás szükségességét pontosan azzal indokolta, hogy a vonatkozó törvények elégtelenek, és nem tartalmaznak rendelkezéseket az ostromállapot és a sürgősségi állapot esetére.

94 E korlátozások a következők: vendéglátóipari egységek bezárása (1. katonai rendelet); a zárt térben megvalósuló kulturális, tudományos, múvészeti, vallási, sport-, szórakoztató rendezvények betiltása (1. katonai rendelet); 100 fósnél nagyobb, nyílt térben megvalósuló események betiltása (1. katonai rendelet); spanyolországi és olaszországi repülójáratok felfüggesztése (1. katonai rendelet), majd a tilalom kiterjesztése más államokra (3. katonai rendelet, 5. katonai rendelet, 7. katonai rendelet), nemzetközi személyszállítás felfüggesztése (7. katonai rendelet); otthoni karantén elrendelése (1. katonai rendelet); fogorvosi szolgáltatások megtiltása a sürgősségi beavatkozások kivételével (2. katonai rendelet); üzletházak, plázák bezárása (2. katonai rendelet); határzár nem EU- vagy EGT-tagállamok állampolgárai vonatkozásában (2. katonai rendelet); keresztelőn, esküvőn vagy temetésen maximum nyolc személy vehet részt (2. katonai rendelet); kijárási korlátozás bevezetése (kivétel munkavégzés, alapvető szükségleti cikkek beszerzése, halaszthatatlan egészségügyi szükséglet, mezőgazdasági munkavégzés) (3. katonai rendelet); 65 év feletti személyek kijárási korlátozása 11-13 óra között (3. katonai rendelet); minden Románia területére lépő személy esetében karantén elrendelése (3. katonai rendelet); Suceava város és 8 község területének karantén alá vonása (6. katonai rendelet), majd Țăndărei város karantén alá vonása (7. katonai rendelet) stb.

95 2020. évi 36. sürgősségi kormányrendelet (Ordonanța de urgență nr. 36/2020 pentru modificarea și completarea unor acte normative, precum și pentru adoptarea unor măsuri pe timpul stării de urgență instituite prin Decretul nr. 195/2020 privind instituirea stării de urgență pe teritoriul României).

96 Alkotmány 53. és 115. cikk.

97 Alkotmány 41. cikk.

98 Alkotmány 53. és 115. cikk. 
Az ostromállapotra és a sürgősségi állapotra vonatkozó bírósági gyakorlattal kapcsolatosan a kézirat lezárásának időpontjáig megállapítható, hogy első fokon folyamatban levő eljárások vannak, például vitatják az 1. katonai rendeletben foglalt vallásos rendezvények betiltásának jogszerủségét.

De lege ferenda az Ostromállapot $r$. helyett a parlament által elfogadott, az alapjog-korlátozás kérdését világosan, teljesen, az alkotmányos elvárásokkal összhangban szabályozó törvényt kell alkotni, hasznosítva a járványhelyzet tapasztalatait.

\section{Egészségügyi vészhelyzet kezelése, koronavírus-járvány}

Az alkotmányban meghatározott, fentebb már tárgyalt esetkörökön túl említésre érdemes - az 1. alfejezetben már említett - sürgósségi helyzet (situaţia de urgenţă), amelyet a válságkezelési rendszerről szóló sürgősségi kormányrendelet úgy határoz meg, mint nem katonai jellegú rendkívüli eseményt, amely az emberi életet vagy egészséget, a környezetet, az anyagi javakat, kulturális értékeket veszélyezteti, és így a rendes állapot helyreállítása érdekében sürgős intézkedések meghozatala szükséges.

Egészségügyi válsághelyzet esetén Romániában háromszintú válságkezelési rendszer müködik: nemzeti, megyei, valamint helyi szinten. Mindhárom szinten megfelelő válságkezelési operatív központokat alakítottak ki, amelyek megosztják egymással az információkat, oda-vissza csatolásos formában egyeztetnek, segítik a döntéshozatalt annak előkészítésével, valamint együttmúködnek más szervekkel.

Nemzeti szinten ${ }^{99}$ múködő minisztériumközi testület, a Vészhelyzetek Országos Bizottsága (Comitetul Naţional Pentru Situații De Urgență) komplex feladatokat lát el a vészhelyzetek kezelése terén. A bizottság döntéshozó tagokból, szakértőkből és a minisztériumok által delegált szakemberekből áll. A bizottság a belügyminiszter közvetlen irányítása alatt múködik. ${ }^{100}$

A polgári védelmi törvény meghatározza ${ }^{101}$ a lakosság, a felszerelés, a kulturális értékek és a környezet védelme érdekében háború vagy katasztrófa esetén szükséges intézkedéseket, és elôírja a vészhelyzeti tervezést válság vagy háború esetére. Az alkotmányos alapjog-korlátozással kapcsolatban már szó esett arról, hogy annak másik szintje az egyes alapjogok és alapszabadságok nevesített korlátozása. Említésre érdemes, hogy az állandó lakhely és

99 Elérhető: https://ec.europa.eu/echo/files/civil_protection/vademecum/ro/2-ro-1.html\#lega (Letöltve: 2020. január 30.).

100 A bizottság összetétele a következő: elnöke a belügyminiszter, alelnöke a Belügyminisztérium egyik államtitkára, tagjai: mindegyik érintett minisztériumból egy államtitkár vagy a központi állami intézmények vezető képviselői, tanácsadók: mindegyik minisztériumból és a központi állami szervből egy vagy két szakértő vagy szakember.

101 A polgári védelemről szóló 2004. évi 481. törvény (Legea nr. 481 din 8 noiembrie 2004 privind protecția civilă). 
tartózkodási hely sérthetetlenségének szabályától a törvény eltérhet például járvány terjedésének megelőzése érdekében.

Ahogy arról már a különleges jogrend alkotmányos és törvényi szabályozását bemutató alfejezetben is szó esett, az Egészségügyi Minisztériumot vezető miniszter meghozza a járványok, valamint fertőző betegségek által előidézett vészhelyzetek megelőzése, illetve kezelése érdekében szükséges intézkedéseket. ${ }^{102}$

Általános járványügyi miniszteri rendelet nem született Romániában, csak a Covid-19járvány miatt fogadták el az egészségügyi miniszter 414/2020. rendeletét, ${ }^{103}$ amely a karanténra és a 297/2020. rendelettel történt módosítása után a koronavírus-tesztelésre vonatkozó szabályokat tartalmazza. A korábbi szabályokban foglaltakhoz képest e miniszteri rendeletek nem vezetnek be alapjogokat érintő új korlátozásokat, csak a korlátozások tartalmát részletezik orvosi szempontok szerint.

Ahogy arról már korábban szó esett, a Covid-19 elnöki dekrétum tételesen felsorolja a korlátozásra kerülő alapjogokat: a mozgásszabadság jogát, a magánélethez való jogot, a lakhely sérthetetlenségét, az oktatáshoz való jogot, a gyülekezési szabadságot, a magántulajdonjogot, a sztrájkjogot és a gazdasági szabadságot korlátozza a dekrétum (lásd az előző gondolati egységben foglaltakat). Azonban ezek között olyan jogok is szerepelnek (például az oktatáshoz való jog), amelyek korlátozására az Ostromállapot r. nem teremt jogalapot (elvi szinten sem szabályozza az oktatáshoz való jog korlátozásának a lehetőségét), ehhez képest a 2020/195. elnöki dekrétum elrendeli, hogy a sürgősségi állapot idejére valamennyi oktatási intézmény szüneteltesse a tevékenységét. ${ }^{104} \mathrm{Az}$ is kétségtelen, hogy az elnöki dekrétumot jóváhagyó 2020/3. parlamenti határozat nem törvény, és a dekrétumot sem emeli törvényi szintre, tehát Romániában az alkotmány ${ }^{105}$ alapján aggályos a dekrétum által bevezetett alapjog-korlátozások alkotmányossága, különösen azon alapjogok tekintetében, ahol a korlátozás lehetőségére nem utal a törvényi szintú szabályozás, azaz Ostromállapot r. Ellentétes szakmai álláspontot is megfogalmaztak, amely szerint az államfő diszkrecionálisan korlátozhatja az alapjogokat és alapszabadságokat, köszönhetően az utólagos parlamenti kontrollnak, ${ }^{106}$ vagyis ezen álláspont szerint az ostromállapotot vagy sürgősségi állapotot elrendelő dekrétum utólagos parlamenti jóváhagyása teljesíti az alkotmány már hivatkozott elvárásait (lásd ezzel kapcsolatosan az előző, alapjog-korlátozással kapcsolatos alfejezetet).

102 Eü. reform tv. 25. cikk (2) bekezdés.

103 A Covid-19-fertőzés által okozott nemzetközi közegészségügyi vészhelyzetben megbetegedettek számára karanténintézkedés bevezetéséről és a járvány következményeinek megelőzésére és korlátozására vonatkozó intézkedések megállapításáról szóló 414/2020. számú rendelet (Ordinul nr. 414/2020 privind instituirea măsurii de carantină pentru persoanele aflate în situația de urgență de sănătate publică internațională determinată de infecția cu COVID-19 și stabilirea unor măsuri în vederea prevenirii și limitării efectelor epidemiei).

104 A Covid-19 elnöki dekrétum 49. cikk.

105 Alkotmány 53. cikk.

106 Apostol Tofan, 2014, 148. o. 
Az elhúzódó járványhelyzetre vonatkozó intézkedések jogi kereteinek újragondolása a 2020. évi 55 . törvény ${ }^{107}$ révén történt meg, vagyis a jogalkotó általános szabályok helyett kifejezetten a koronavírus-járvánnyal kapcsolatban alkotott meg sajátos szabályokat. A sürgősségi állapot fenntartása helyett Romániában riadóállapot van a kézirat lezárásának pillanatában is, és a jogszabály ebben az időszakban is korlátoz bizonyos alapjogokat. A korlátozásoknak ideiglenes jellegúeknek kell lenniük, valamint a törvény a fokozatosság elvét írja elő a korlátozások foganatosítására, továbbá deklaratív jelleggel kimondja, hogy a korlátozások célja az élet és az egészség védelme. E törvény a riadóállapot fogalmát is megalkotta: a riadóállapot olyan rendkívüli kiterjedésú és intenzitású különleges helyzetre adott intézkedésrendszer, amely ideiglenes és a helyzet jelenlegi vagy jövőbeni súlyosságával arányos, és amely szükséges az életet, az egészséget, a környezetet, a fontos anyagi és kulturális értékeket vagy a tulajdont fenyegető veszélyek megelőzésére és elhárítására. A riadóállapotot helyi, megyei vagy országos szinten is el lehet rendelni a kormány hatáskörében, legfeljebb 30 napra, és újabb 30 napos időszakokra meghosszabbítható. ${ }^{108} \mathrm{~A}$ jogszabály lehetővé teszi riadóállapot alatt az ideiglenes kilakoltatást a fertőzött övezetekből; hatósági vagy otthoni karantén elrendelését; a gyülekezési jog korlátozását; kulturális, tudományos, vallási, sportrendezvények korlátozását vagy megtiltását; a mozgásszabadság korlátozását; adott területek lezárását; épületek, települések vagy térségek karantén alá helyezését; a közlekedési szolgáltatások korlátozását vagy megtiltását; határátkelők ideiglenes lezárását; intézmények vagy vállalkozások múködésének korlátozását vagy ideiglenes megtiltását; vendéglátóipari egységek múködésének korlátozását vagy megtiltását; bevásárlóközpontok tevékenységének felfüggesztését; kötelező maszkviselést; intézményekbe és vállalkozásokba történő belépésnél a kötelező járványügyi szứrés elrendelését (érintésmentes lázmérővel); a szabadságok megszakítása elrendelhető; munkavégzés ideje módosítható, hogy a munkakezdés időpontja egy-egy órás eltolódással kezdődjön a különféle munkavállalói csoportok számára; kiemelt gazdasági területeken a sztrájkjog gyakorlása ideiglenesen tiltható; online oktatás bevezethetó.

\section{4. Összegzés}

Ahogy arról már korábban is szó esett, a különleges jogrend román és a hazai hatályos szabályozása közötti lényegi eltérés az, hogy míg az előbbi négy szabályozási tárgykört (ostromállapot, sürgősségi állapot, mozgósítás és hadiállapot), addig ahhoz képest az utóbbi, magyar hatályos szabályozás hat tényállást (rendkívüli állapot, szükségállapot, veszély-

107 A Covid-19-járvány megelőzésére és az azok elleni küzdelemre irányuló egyes intézkedésekrôl szóló 2020. évi 55. törvény (Legea nr. 55 din 15 mai 2020 privind unele măsuri pentru prevenirea și combaterea efectelor pandemiei de COVID-19).

108 Lásd például a 2020/1065. kormányhatározatot (Hotărârea nr. 1.065 din 11 decembrie 2020 privind prelungirea stării de alertă pe teritoriul României începând cu data de 14 decembrie 2020, precum și stabilirea măsurilor care se aplică pe durata acesteia pentru prevenirea și combaterea efectelor pandemiei de COVID-19), amely 2020. december 14-től hosszabbítja meg a riadóállapotot 30 nappal. 
helyzet, váratlan támadás, megelőző védelmi helyzet, terrorveszélyhelyzet) állapít meg. A román ostrom- és sürgősségi állapotot érintő szabályozással párhuzamosan az Alaptörvényünk szerint a rendkívüli vagy szükségállapot kihirdetésére kerül sor. Lényegi eltérés azonban, hogy a román szabályozásban - speciális jelleggel - katonai rendelet és sürgősségi kormányrendelet megalkotására van lehetőség, míg a magyar szabályozás rendeletalkotásra ad lehetőséget. ${ }^{109}$

A román szabályozásban a parlamenti jóváhagyással kiadott elnöki döntés alapján kialakuló katonai tényállásokhoz, azaz a mozgósításhoz és a hadiállapothoz képest a magyar szabályozás szerint az Országgyúlés hadiállapot kinyilvánítása vagy idegen hatalom fegyveres támadásának közvetlen veszélye (háborús veszély) esetén kihirdeti a rendkívüli állapotot. A rendkívüli állapot idején a Honvédelmi Tanács gyakorolja az Országgyúlés által rá átruházott jogokat a köztársasági elnök jogai mellett, amelyhez társulnak a Kormány jogai. A Honvédelmi Tanács rendeletet alkothat, amely a rendkívüli állapot megszúnésével hatályát veszti, kivéve, ha az Országgyưlés a rendelet hatályát meghosszabbítja. A szükségállapot idején az Országgyúlés akadályoztatása esetén a köztársasági elnök dönt a Magyar Honvédség bevetéséről. Ebben az időszakban a rendkívüli intézkedéseket rendeleti úton a köztársasági elnök vezeti be. A rendeleti úton bevezetett rendkívüli intézkedések harminc napig maradnak hatályban, kivéve, ha hatályukat az Országgyưlés - akadályoztatása esetén az Országgyúlés honvédelmi ügyekkel foglalkozó bizottsága - meghosszabbítja. A köztársasági elnök rendelete a szükségállapot megszúnésével hatályát veszti. A magyar hatályos szabályozás szerint a különleges jogrend kihirdetéséhez az országgyưlési képviselők kétharmadának szavazata szükséges. Ha az Országgyűlés akadályoztatva van, a köztársasági elnök jogosult a hadiállapot kinyilvánítására, a rendkívüli állapot kihirdetésére és a Honvédelmi Tanács létrehozására, valamint a szükségállapot kihirdetésére. Rendkívüli állapot vagy szükségállapot idején az Országgyúlés nem mondhatja ki feloszlását, és nem oszlatható fel. A magyar és a román szabályozás összehasonlítása során mindegyik román tényállás esetén egyértelmúen látható az elnök markáns szerepe. Fontos itt ismételten arra is kitérni, hogy a Covid-19-járvány miatt a román szabályozás - speciális jelleggel - törvényi úton bevezette a riadóállapot fogalmát is. Ezzel kapcsolatban jelezni szükséges, hogy megfontolásra érdemes egy esetleges hasonló jogintézmény magyar jogrendszerbe illesztésének vizsgálata. A román Legfelsőbb Honvédelmi Tanácshoz hasonló szerv - a Honvédelmi Tanács - a hatályos magyar szabályozásban is létezik; az érdemi eltérést az jelenti, hogy a magyar Honvédelmi Tanács rendeletet alkothat; további különbség, hogy a román testület a különleges jogrend kihirdetését megelőzően is múködik. A magyar szabályozáshoz képest lényegi eltérést képez az a korábbiakban már jelzett tény, hogy Romániában az elnök szerepe kifejezetten hangsúlyos, erre nyújt - többek között - jó példát, hogy az ostromállapot és a sürgősségi állapot rendjének szabályai szerint Románia elnöke elnöki rendelettel (dekrétum) 
az egész országban vagy egyes területi-közigazgatási egységekben elrendelheti az ostromállapotot vagy a sürgősségi állapotot.

A román szabályozás lényegének bemutatását szolgálja a következő táblázat.

\begin{tabular}{|c|l|l|}
\hline & \multicolumn{1}{|c|}{ Ostromállapot, sürgősségi állapot } & \multicolumn{1}{|c|}{ Mozgósítás, hadiállapot } \\
\hline Szabályozás szintje & Alkotmányos, törvényi és rendeleti szint \\
\hline Elrendelési okok & $\begin{array}{l}\text { Az állam szuverenitását vagy } \\
\text { területi integritását; } \\
\text { a nemzetbiztonságot vagy az al- } \\
\text { kotmányos demokráciát fenyegető } \\
\text { súlyos, aktuális vagy elkerülhe- } \\
\text { tetlen veszély. }\end{array}$ & $\begin{array}{l}\text { Az ország elleni fegyveres } \\
\text { támás esetén. }\end{array}$ \\
\hline Elrendelés & Elnök (az országgyúléssel együttmúkködve) \\
\hline Felhatalmazott & Elnök & \multicolumn{2}{|l|}{} \\
\hline Gyakorlati esetek & $\begin{array}{l}\text { Sürgősségi állapot: egy alkalommal } \\
\text { (202o: Covid-19). }\end{array}$ & Nem rendelték el. \\
\hline $\begin{array}{l}\text { Különleges jogrendnek nem } \\
\text { minősülő rendkívüli helyzet }\end{array}$ & Sürgősségi helyzet, riadóállapot \\
\hline
\end{tabular}

\section{0. táblázat \\ Különleges jogrendek a román szabályozásban \\ Forrás: a szerzô sajátösszeállitása}

Magyarország Kormánya 2020. november elején az Országgyúlésnek benyújtotta a Magyarország Alaptörvényének kilencedik módosításáról szóló tervezetet, amelyet az Országgyưlés 2020. december 15. napján elfogadott, és a vonatkozó rendelkezések 2023-ban lépnek hatályba ${ }^{110}$ Ennek értelmében - a román jogintézményekhez képest - az Alaptörvény a kilencedik módosítását követően már csak három különleges jogrendi tényállást fog szabályozni: a hadiállapotot, a szükségállapotot és a veszélyhelyzetet. E módosítással - külföldi példák nyomán - a jogalkotó átláthatóbbán ${ }^{11}$ kívánja tenni a korábbi hat helyett három esetkörre módosuló különleges jogrendi tényállások rendszerét, amely a fegyveres védelmi és biztonsági tevékenységekben érintett szervezetekre vonatkozó szabályokkal egy korszerủbb, a változó biztonsági környezethez jobban alkalmazkodó és az elmúlt évek válságkezeléseinek tapasztalataira építő, hatékony rendszer kialakítására törekszik. A módosítás a korszerủsítés és a rendszerszintủ megújítás mellett számos ponton többletgaranciákat épít be

110 T/13647. számú tervezet: www.parlament.hu/irom41/13647/13647.pdf (Letöltve: 2020. december 15.). A módosítást még nem hirdették ki a Magyar Közlönyben.

111 Vö.: Till, 2017, 73-75. o. 
a védelmi és biztonsági funkciók ellátásának szervezeti, múködési és szabályozási keretei vonatkozásában is. A különleges jogrend intézményrendszerében - a módosítás eredményeként - a köztársasági elnök és a Honvédelmi Tanács nem kap szerepet, és ennek következményeként a Kormány szerepe megerősödik, amit jelez a különleges jogrendre vonatkozó közös szabályokban foglalt rendeletalkotási jogkör hangsúlyossá válása. A módosítás alapján a jövőbeli magyar és román szabályozás a tényállások száma és átláthatósága tekintetében hasonló lesz. A 2023-ban hatályba lépő magyar szabályozás és a román között egyértelmú eltérés az, hogy a román elnöki túlsúllyal szemben a magyar szabályozásban a Kormány kap meghatározó szerepet, annak markáns rendeletalkotási jogkörével. Jelezni kell azt is, hogy a 2023-as új szabályozás létrehozza a magyar szabályozásban is az elsődlegesen katonai tényállásként értelmezhető hadiállapotot, ami - ebből a szempontból - a magyar szabályozást közelíteni fogja a román szabályozáshoz.

A fentiekben már szó esett arról, hogy az egészségügy reformjáról szóló törvény nem szabályozza külön az egészségügyi veszélyhelyzetet, mert a román jogalkotó az egészségügyi veszélyhelyzet kezelésére a sürgősségi állapot jogintézményét tartja megfelelőnek. Az állami egészségügyi intézményrendszer feladatai között szerepel a járványhelyzetek megelőzése, a járványügyi riadóállapot elrendelése és a járványok ellenőrzése, de a járványok által kiváltott sürgősségi helyzetekre vonatkozó intézkedéseket a törvény miniszteri rendelet szabályozási körébe utalja. ${ }^{112}$ Egyetlen törvényes rendelkezés van, amelyet még érdemes megemlíteni: az állami hatóságok járvány idején jóváhagyhatják nem engedélyezett gyógyszerek alkalmazását is. ${ }^{113}$

Alkotmányjogi szempontból érdekes, hogyan múködnek a gyakorlatban a fenti rendelkezések. Az Ostromállapot r. járványügyi veszélyhelyzet kezelésére nem alkalmas, ezért is volt indokolt a külön jogszabály megalkotása, viszont ezen túlmenően egységes, pontos szabályozás kidolgozása a jövőben indokolt lenne.

A járvány alatt alkotmánybírósági döntések sora foglalkozott az alapjogok korlátozásának kérdésével, így az alkotmánybíróság több döntésével korrigálta a kormány sokszor elsietett, az alkotmányos rendbe nem integrált intézkedéseit. ${ }^{114} \mathrm{Az}$ alkotmánybíróság megállapította például, hogy a sürgősségi állapotban a kijárási tilalmat megszegőkre kirótt büntetéseket előiró jogszabály alkotmánysértő (mert alapjog-korlátozáshoz kapcsolódnak, ezért ezeket kizárólag törvényben és nem törvényerejü kormányrendeletben lehet elő́rni);;15 a sürgősségi kormányrendeletben vagy miniszteri rendeletben meghatározott karanténkötelezettség alkotmányellenes (az alapjog korlátozása törvényi szabályozást igényel); megállapította, hogy a riadóállapot kihirdetéséhez nem szükséges a parlament jóváhagyása, mert az egy alkotmánynál alacsonyabb szinten megalkotott jogintézmény, és a végrehajtó hatalmi

112 Eü. reform tv. 5-6. és 25. cikk.

113 Eü. reform tv. 5-6. és 25. cikk. 703. cikk.

114 Vö.: 2020/152. ABD, 2020/157. ABD, 2020/397. ABD, 2020/457. ABD, 2020/458. ABD, 2020/581. ABD.

115 Ez körülbelül 300000 kirótt szabálysértési bírság jogellenességét jelentette. 
ág élhet e jogkörrel az alkotmányos keretek között; kimondta, hogy alkotmánysértő a polgármesterek és tanácsosok (önkormányzati képviselők) mandátumát meghosszabbító sürgősségi kormányrendelet (mert ilyen hosszabbítást kizárólag törvény rendelhet el).

\section{Irodalomjegyzék}

Apostol Tofan, D. (2014) Drept administrativ, volumol I. 3. kiadás. Bukarest: C. H. Beck

Kelemen, R. (2020) 'Különleges jogrend az Európai Unió egyes tagállamainak alkotmányaiban' in Farkas, Á., Kelemen, R. (szerk.) (2020) Szkülla és Kharübdisz közöttTanulmányok a különleges jogrend elméleti és pragmatikus kérdéseiröl, valamint nemzetközi megoldásairól. 1. kiadás. Budapest: Magyar Katonai Jogi és Hadijogi Társaság

Meltzer, M., Stefanescu, L., Ozunu, A. (2018) 'Keep Them Engaged: Romanian County Inspectorates for Emergency Situations' Facebook Usage for Disaster Risk Communication and Beyond', Sustainability, 10(5), 1-24. o.

Országgyúlés Hivatala Képviselői Információs Szolgálat (2016) Kormányhatáskörök és parlamenti ellenôrzés rendkivüli állapot esetére az Európai Unió tagországaiban [Online]. Elérhető: https://tinyurl.hu/SsjG/ (Letöltve: 2020. január 14.)

SzABó, Cs., HoRváth, L. (2012) 'Magyarország Alaptörvényének és a Magyar Köztársaság Alkotmányának összevetése a különleges jogrend vonatkozásában', Hadmérnök, 7(2), 395404. o.

TÁLAs, P. (2016) 'A terrorveszélyhelyzet-diskurzus margójára', Nemzetés Biztonság, 9(1), 40-47. o.

TANASESCU, E. (2020) 'COVID-19 and constitutional law: Romania' in Serna de la Garza, J. M. (szerk.) Covid-19 and Constitutional Law. Covid-19 et droit constitutionnel. 1. kiadás. México: Universidad Nacional Autónoma de México

TilL, Sz. (2017) 'A különleges jogrendi kategóriarendszer egyszerűsítésének jövőbeli esélyei', Iustum Aequum Salutare, 13(4), 55-75. o.

VARGA, A. (2019) Román alkotmányjog. Budapest-Kolozsvár: Forum Iuris

Venice Commission (2020) Interim Report on the Measures Taken int he EU Member States as a Result of the Covid-19 Crisis and Their Impact on Democracy, the Rule of Law and Fundamental Rights (Opinion No. 995/2020) [Online]. Elérhető: www.venice.coe.int/webforms/documents/ default.aspx?pdffile=CDL-AD(2020)018-e (Letöltve: 2020 . december 15.)

Veress, E. (2006) 'Elnök és kormány viszonya Romániában: a félparlamentarizmus gyakorlata', Magyar Kisebbség, 10(1-2), 299-311. o. 